\title{
Enhancement of rice (Oryza sativa L.) physiological and yield by application of nano-titanium dioxide
}

\author{
Rutairat Phothi ${ }^{1}$, Chonlada Dechakiatkrai Theerakarunwong ${ }^{2 *}$ \\ ${ }^{1}$ Environmental Science Program, Faculty of Science and Technology, Nakhon Sawan Rajabhat University, \\ Nakhon Sawan 60000, Thailand \\ ${ }^{2}$ Chemistry Program, Faculty of Science and Technology, Nakhon Sawan Rajabhat University, Nakhon \\ Sawan 60000, Thailand
}

*Corresponding author: chonlada.dechakiatkrai@gmail.com

Abstract

Engineered nanoparticles (ENPs) are reported as potentially response to rice physiological and production. The research aimed to investigate the effects of suspended nano-titanium dioxide $\left(\mathrm{sn}-\mathrm{TiO}_{2}\right)$, which is non-toxic to ecology and on the physiology and yield of Thai rice. Selected rice cultivars of RD41 were soaked and sprayed with three difference concentrations of $\mathrm{sn}-\mathrm{TiO}_{2}\left(\mathrm{TO}_{0.01} \mathrm{~T}_{\mathrm{T}} \mathrm{T} .02\right.$, T0.03 and C) through growing period. Tiller number per plants, stem height and leaf chlorophyll of rice RD41 cultivars were analyzed at tillering (40 days), flowering (70 days), and final harvesting (100 days), whereas the biomass and yield were evaluated at final harvesting (100 days). The results showed the concentration of T0.03 had highest effects on rice RD41 for all studies, which showed non-significance of differences at $p \leq 0.05$ compared to T0.02. Application of T0.01, T0.02 and T0.03 treatments increased total biomass $33.69,42.66$ and $47.91 \mathrm{~g}$ plant ${ }^{-1}$, respectively, compared to control (30.49). Application of T0.02 enhanced the plant growth and caused increases in the yield of rice, which impacted food availability. According to the results obtained, the function of sn- $\mathrm{TiO}_{2}$ played a positive role in many aspects. For instance, $\mathrm{sn}-\mathrm{TiO}_{2}$ could increase light harvesting to activate the photosynthesis rate of rice RD41. Besides, nitrogen metabolism was improved by $\mathrm{sn}-\mathrm{TiO}_{2}$ and stimulated protein and pigments content. Moreover, our observed decreasing in injury indices compared to the control group, which caused improvement in cell enlargement, cell elongation and plant growth. Atomic absorption spectrometric result ensured that there is no unforeseen Ti contamination in all part of rice. These findings are important supplementary factors to the application of $\mathrm{sn}-\mathrm{TiO}_{2}$ for the crop yield and quality with a proper concentration for their benefits potential.

Keywords: sn- $\mathrm{TiO}_{2}$, Rice, Physiology, Yield, AAS.

Abbreviations: T0.01_titanium dioxide $0.01 \% \mathrm{w} / \mathrm{v}$; T0.02_titanium dioxide $0.02 \% \mathrm{w} / \mathrm{v}$; T0.03_titanium dioxide $0.03 \% \mathrm{w} / \mathrm{v}$; C_control.

\section{Introduction}

The sn- $\mathrm{TiO}_{2}$ is ultrafine material with the particle size in the range of $1-100 \mathrm{~nm}$. Compare to the non-nanoscale $\mathrm{sn}^{-\mathrm{TiO}_{2}}$ element, the nanomaterials exhibit a promising unique physical and chemical properties due to their large specific surface area. Increasing evidences in the literature, suggest that the $\mathrm{sn}-\mathrm{TiO}_{2}$ application are useful for plant protection. They also boost plants ability to take up other nutrients by enhanced total chlorophyll biosynthesis and enzymatic activities, resulting in high yield (Cigler et al., 2010; Kovacik et al., 2014; Lyu et al., 2017). Several studies have explained and proposed the mechanism of actions of $\mathrm{Ti}$ as a growth promoter for plants, including nitrogen fixation (Konishi and Tsuge, 1936) and their influence on plant metabolism by increasing absorption of nutrient elements (Simon et al., 1988), redox reactions (Carvajal et al., 1995) and stimulation of enzymatic activities and photosynthesis (Carvajal and Alcaraz, 1998). However, the plant response to $\mathrm{sn}-\mathrm{TiO}_{2}$ is still unclear and depends on the variation of different factors in environmental condition. Studies on biomass of crops have reported that plants uptake $\mathrm{Ti}$ ion by root uptake, leaf absorption and seed absorption (Lyu et al., 2017). Ti and Fe interact with one another, in which $\mathrm{Ti}$ can induce the expression of gene and enhance $\mathrm{Fe}$ uptake, when plant encounter Fe deficiency (Lyu et al., 2017). Moreover, the efficiency of root uptake of $\mathrm{sn}-\mathrm{TiO}_{2}$ depends on the particle size, which means root appears to be size selective (Tripathi et al., 2017). Wang et al. (2013) studied the effect of nanosized $\mathrm{sn}-\mathrm{TiO}_{2}$ on watermelon and reported that $\mathrm{sn}-\mathrm{TiO}_{2}$ entered leaf symplast through direct penetration. Hatami and Ghorbanpour, (2014) and Cox et al., (2016) soaked plant seeds in $\mathrm{sn}-\mathrm{TiO}_{2}$ and reported increase in nutrient absorption due to NPs penetration through seed coat, resulting in the enhancement of seed germination, root elongation and improved seedling growth. This research focus on replacing the conventional pesticide through the use of non-toxic $\mathrm{Sn}-\mathrm{TiO}_{2}$ as a disinfection of seedling surface and foliar spray to improve the seedling growth, physiological and photosynthesis attributes of rice RD41. Recently, it has been indicated that $\mathrm{sn}-\mathrm{TiO}_{2}$ can influence plant growth and photosynthetic activity. The results 
revealed that $\mathrm{sn}-\mathrm{TiO}_{2}$ can significantly affect plant's biomass. Notably, low concentration of $\mathrm{sn}-\mathrm{TiO}_{2}$ caused significant improvement of plant nutrients, photosynthetic, antimicrobial and environmental-friendly over high concentration of sn- $\mathrm{TiO}_{2}$ (Jaberzadeh et al., 2013). There are few scientific literatures addressing the issue of the application of $\mathrm{sn}-\mathrm{TiO}_{2}$ to directly promote the plant production and rate of photosynthesis. However, previous research has shown that $\mathrm{sn}-\mathrm{TiO}_{2}$ enhanced crop yield and suppress plant disease. Theerakarunwong and Chuaychai (2013) reported the efficacy of $\mathrm{sn}-\mathrm{TiO}_{2}$ nanoparticles on the activity of antioxidant in Mungbean. The conclusions obtained from these studies found that surface sterilization of explants with $\mathrm{sn}-\mathrm{TiO}_{2}$ instead of high toxicity sodium hypochlorite $(\mathrm{NaOCl})$ and mercury chloride $\left(\mathrm{HgCl}_{2}\right)$ was successfully achieved, while sn- $\mathrm{TiO}_{2}$ was not toxic to plant tissue. Moreover, nano $\mathrm{sn}^{-\mathrm{TiO}_{2}}$ increases photosynthesis and plant growth. The other research has reported that $\mathrm{sn}-\mathrm{TiO}_{2}$ could greatly decreased infection of leaf and pea pod of Vigna unguiculata. Under UV irradiation, $\mathrm{sn}-\mathrm{TiO}_{2}$ induced the production of reactive oxygen species (ROS), which correlated to cell damage, by destruction of cell membrane and DNA damage (Owlade and Ogunleti, 2008). The report presented the potential influence of $\mathrm{sn}-\mathrm{TiO}_{2}$ on the yield of chickpea under cold weather since $\mathrm{sn}-\mathrm{TiO}_{2}$ inhibited cell metabolisms in plants, leading to reduce cell damage and increased the chlorophyll A, chlorophyll B and carotenoid contents (Mohammadi et al., 2014). Considering the above mentioned impact of $\mathrm{sn}-\mathrm{TiO}_{2}$ nanoparticles on physiological properties, the aims of this study was focused on the potential impacts of $\mathrm{sn}-\mathrm{TiO}_{2}$ on rice growth and performance. The results of this study can contribute to increase crop yield against different stresses.

\section{Results and Discussion}

\section{Effect of $\mathrm{Sn}-\mathrm{TiO}_{2}$ on the tiller number and stem height of rice RD41}

Tiller number of rice RD41 was much higher than control group, which was treated with T0.03 by $8.17,8.33$ and 9.00 tiller per plant. Unlike control, plants showed lower tillers per plant were slightly increased by $7.00,7.33$ and 7.50 tiller per plant at T0.01, T0.02, T0.03, respectively (Table 1). The tiller per plant of both treated T0.01 and T0.02 of rice RD41 showed no significant difference, when compared with control group. The observed increasing tiller number was due to photosynthetic rate and yield as shown in Table 1. The T0.03 treatment showed significant effect in plant growth. The stem height of rice RD41 at tillering stage was $89.42 \mathrm{~cm}$, while the stem height of the control, T0.01 and T0.02 were 85.92, 85.33 and $84.50 \mathrm{~cm}$, respectively. At final harvesting stage, treatments showed no significant difference by 112.83 , $113.50,115.83$ and $118.50 \mathrm{~cm}$ (Table 1). Plant growth and cell enlargement under proper concentration of $\mathrm{sn}-\mathrm{TiO}_{2}$ can be attributed to nitrogen metabolism by modulating inorganic-toorganic conversion rate (Karami and Sepehri, 2018)

\section{The effect of $\mathrm{Sn}^{-\mathrm{TiO}_{2}}$ on leaf chlorophyll of rice RD41}

The total chlorophyll content of plants was increased under tillering and flowering stage, whereas under final harvesting stage, total chlorophyll was decreased. The net chlorophyll content at all stages was as following: $\mathrm{C}<\mathrm{T} 0.01<\mathrm{T} 0.02<\mathrm{T} 0.03$.
For example, total chlorophyll in leave under tillering stage was found to be $16.19,23.03,28.82$ and $38.84 \mathrm{mg} \mathrm{Chl} / \mathrm{g}$ fresh weight, respectively (Table 2). For spinach, bulk $\mathrm{sn}^{-\mathrm{TiO}_{2}}$ boosted total chlorophyll and rubisco activity, leading to the increasing photosynthesis rate (Linglan et al., 2008). These results are in agreement with some other findings indicating that $\mathrm{sn}-\mathrm{TiO}_{2}$ is beneficial to cucumber photosynthesis (Cui et al., 2009). Moreover, $\mathrm{TiO}_{2}$ nanoparticles induce chlorophyll and carotenoid contents by inhibiting those pigments from reactive oxygen species leading to capture more sunlight for photosynthesis (Mohannadi et al., 2014; Karami and Sepehri, 2018). Notably, this enhancement yield by $\mathrm{sn}-\mathrm{TiO}_{2}$ directly linked to suppress plant disease and also to the potential nutritional uptake (Servin et al., 2015; Mohammadi et al., 2014).

\section{The effect of $\mathrm{sn}-\mathrm{TiO}_{2}$ on the panicle number of rice RD41}

The results showed that panicle number of rice cultivars RD41 was increased after germinated with the suspension of $\mathrm{sn}-\mathrm{TiO}_{2}$ in plastic pots compare to the control group. The average of panicle number of rice cultivars RD41 at 100 days were 6.17, $6.33,7.17$ and 7.67 panicle per plant under C, T0.01, T0.02 and T0.03), respectively. For 3 treatments, panicle per plant was increased by $2.70,16.22$ and $24.32 \%$, as compared with the control. The concentration of both $\mathrm{T0} 0.02$ and $\mathrm{T} 0.03 \mathrm{sn}^{-\mathrm{TiO}_{2}}$ caused more positive effect than T0.01 and control group, with no significant difference. The $\mathrm{sn}-\mathrm{TiO}_{2}$ at high concentration trends to exhibit more positive effect on seed germination, tiller number, dry mass, etc. The toxicity induced by higher concentration $(0.03 \% \mathrm{w} / \mathrm{v})$ may have been produce the more toxic compounds, which is very important factor to consider during the study of $\mathrm{Ti}$ on plants. These results are consistent with Zahra et al. (2017), who have shown that sn$\mathrm{TiO}_{2}$ had positive impact on rice growth performance and reduce the infection of rice. Moreover, Owolade et al. (2008) reported that $\mathrm{sn}-\mathrm{TiO}_{2}$ enhanced the yield of cowpea by spraying method, which is relevance to chlorophyll content, leading to increase in photosynthesis rate.

\section{The effect of $\mathrm{sn}-\mathrm{TiO}_{2}$ on the biomass of rice RD41}

Dry biomass of shoot, root and total biomass were increased by $\mathrm{sn}-\mathrm{TiO}_{2}$. Upon control, T0.01, T0.02 and T0.03, total biomass was increased $30.49,33.69,42.66$ and $47.91 \mathrm{~g}$ per plant, respectively (Fig 1). Total biomass of rice RD41 was obviously increased by T0.02 and T0.03. In contrast, no significant increases in total dry biomass were observed upon T0.01 and control group. In support of this finding, a recent study in wheat treated with bulk sn- $\mathrm{TiO}_{2}$ at the concentration of $\mathrm{T} 0.01-\mathrm{T} 0.03 \mathrm{sn}-\mathrm{TiO}_{2}$ indicated that bulk $\mathrm{sn}-\mathrm{TiO}_{2}$ induced wheat biomass. $\mathrm{TiO}_{2}$ affects plant biomass status by a combination of enhancing plant nutrition level and reducing disease presence, leading to an increased photosynthetic rate (Owlade and Ogunleti., 2008; Servin et al., 2015).

\section{The effect of $\mathrm{sn}-\mathrm{TiO}_{2}$ on the panicle weight of rice RD41}

The panicle weight of RD41 dry weights at age 100 days were 3.30, 3.74, 4.21 and $4.44 \mathrm{~g}$ (C, T0.01, T0.02 and T0.03) respectively (Table 3 ), indicating a percentage as follows; 13.32\%, 27.57\% and 34.47\% (T0.01, T0.02 and T0.03), respectively, compared with the control group. Again, the 
Table 1. Tiller number per plan and stem height of rice RD41. Rice samples soaked and sprayed with sn- $\mathrm{TiO}_{2}$ for 100 days; $\mathrm{TO}_{0.01}$, T0.02, T0.03 and C. The data represent the mean \pm SE. Different letters indicate significant differences among treatments at $p \leq 0.05$.

\begin{tabular}{lccccc}
\hline & $\begin{array}{c}\text { Days of } \\
\text { exposure } \\
\text { sn-TiO } 2\end{array}$ & $\mathrm{C}$ & T0.01 & T0.02 \\
\hline Tiller & 40 days & $7.00 \pm 0.37 \mathrm{~b}$ & $7.33 \pm 0.33 \mathrm{ab}$ & $7.17 \pm 0.31 \mathrm{ab}$ & $8.17 \pm 0.40 \mathrm{a}$ \\
number per & 70 days & $7.33 \pm 0.42 \mathrm{a}$ & $7.50 \pm 0.43 \mathrm{a}$ & $7.33 \pm 0.49 \mathrm{a}$ & $8.33 \pm 0.33 \mathrm{a}$ \\
plan & 100 days & $7.5 \pm 0.34 \mathrm{~b}$ & $7.67 \pm 0.33 \mathrm{ab}$ & $7.67 \pm 0.49 \mathrm{ab}$ & $9.00 \pm 0.63 \mathrm{a}$ \\
\hline Stem & 40 days & $85.92 \pm 0.99 \mathrm{~b}$ & $85.33 \pm 1.20 \mathrm{~b}$ & $84.50 \pm 1.02 \mathrm{~b}$ & $89.42 \pm 0.84 \mathrm{a}$ \\
height & 70 days & $107.83 \pm 1.53 \mathrm{ab}$ & $107.05 \pm 1.73 \mathrm{~b}$ & $111.50 \pm 2.70 \mathrm{ab}$ & $114.27 \pm 2.20 \mathrm{a}$ \\
(cm) & 100 days & $112.83 \pm 1.78 \mathrm{a}$ & $113.50 \pm 0.92 \mathrm{a}$ & $115.83 \pm 2.85 \mathrm{a}$ & $118.50 \pm 1.43 \mathrm{a}$ \\
\hline
\end{tabular}

(a)

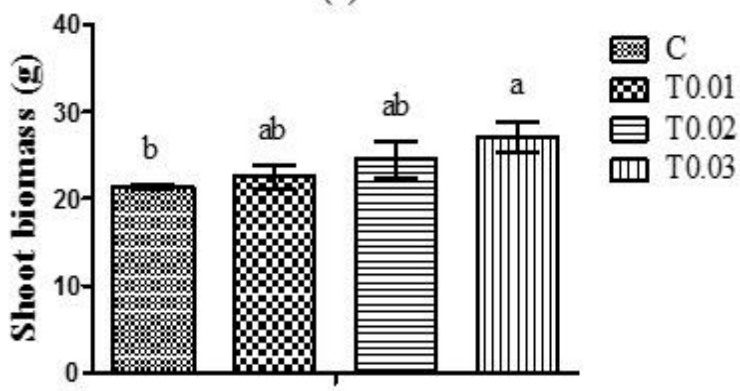

(b)

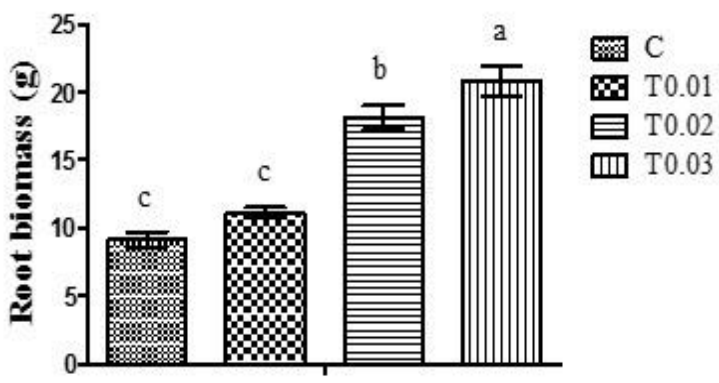

(c)

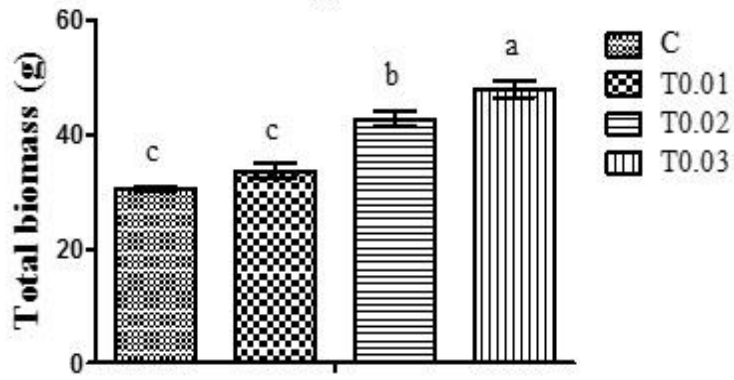

Fig 1. Shoot biomass (a), root biomass (b), and total biomass (c) of rice RD41. Rice samples by soaked and sprayed with $s n-\mathrm{TiO}_{2}$ for 100 days; T0.01, T0.02, T0.03 and C. The data represent the mean \pm SE. Different letters indicate significant differences among treatments at $p \leq 0.05$

Table 2. Leaf chlorophyll of rice RD41. Rice samples by soaked and sprayed with sn- $\mathrm{TiO}_{2}$ for 100 days; T0.01, T0.02, T0.03 and C. The data represent the mean \pm SE. Different letters indicate significant differences among treatments at $p \leq 0.05$.

\begin{tabular}{|c|c|c|c|c|c|}
\hline & $\begin{array}{l}\text { Days of exposure } \\
\text { sn- } \mathrm{TiO}_{2}\end{array}$ & $C$ & T0.01 & T0.02 & T0.03 \\
\hline \multirow[t]{3}{*}{$\mathrm{Chl}$ a } & 40 days & $9.73 \pm 1.67 b$ & $12.83 \pm 1.35 a b$ & $14.71 \pm 0.61 a$ & $16.52 \pm 0.37 a$ \\
\hline & 70 days & $11.07 \pm 2.23 b$ & $14.50 \pm 0.13 a b$ & $15.66 \pm 0.06 a$ & $17.50 \pm 0.55 a$ \\
\hline & 100 days & $11.61 \pm 0.18 \mathrm{~b}$ & $12.22 \pm 0.90 b$ & $12.93 \pm 0.35 b$ & $14.91 \pm 0.42 a$ \\
\hline \multirow[t]{3}{*}{ Chl b } & 40 days & $6.46 \pm 0.99 b$ & $10.20 \pm 3.05 b$ & $14.11 \pm 2.44 b$ & $22.33 \pm 2.08 a$ \\
\hline & 70 days & $4.40 \pm 2.54 b$ & $2.34 \pm 1.35 a$ & $1.75 \pm 1.01 \mathrm{a}$ & $4.28 \pm 2.47 a$ \\
\hline & 100 days & $7.54 \pm 0.31 b$ & $8.82 \pm 1.34 b$ & $10.02 \pm 0.74 b$ & $15.47 \pm 1.52 \mathrm{a}$ \\
\hline Total & 40 days & $16.19 \pm 2.65 c$ & $23.03 \pm 4.35 b c$ & $28.82 \pm 3.04 a b$ & $38.84 \pm 1.91 a$ \\
\hline \multirow[t]{2}{*}{ Chl } & 70 days & $20.84 \pm 4.73 b$ & $32.86 \pm 1.47 a$ & $35.31 \pm 1.07 a$ & $39.74 \pm 2.56 a$ \\
\hline & 100 days & $19.15 \pm 0.49 b$ & $21.04 \pm 2.24 b$ & $22.95 \pm 1.09 \mathrm{~b}$ & $30.38 \pm 1.95 a$ \\
\hline
\end{tabular}


Table 3. Panicle number per plant, panicle weight, fill grain, unfilled grain and percent fill grain per total grain of rice RD41. Rice samples soaked and sprayed with $\mathrm{sn}-\mathrm{TiO}_{2}$ for 100 days; $\mathrm{TO} .01, \mathrm{TO} .02, \mathrm{TO} .03$ and $\mathrm{C}$. The data represent the mean $\pm \mathrm{SE}$. Different letters indicate significant differences among treatments at $p \leq 0.05$.

\begin{tabular}{lllll}
\hline yield & $\mathrm{C}$ & T0.01 & T0.02 & T0.03 \\
\hline Panicle number & $6.17 \pm 0.40 \mathrm{~b}$ & $6.33 \pm 0.21 \mathrm{~b}$ & $7.17 \pm 0.48 \mathrm{ab}$ & $7.67 \pm 0.33 \mathrm{a}$ \\
Panicle weight & $3.30 \pm 0.21 \mathrm{~b}$ & $3.74 \pm 0.37 \mathrm{ab}$ & $4.21 \pm 0.14 \mathrm{a}$ & $4.44 \pm 0.30 \mathrm{a}$ \\
Number of filled grain per panicle & $105.32 \pm 7.78 \mathrm{c}$ & $114.73 \pm 8.43 \mathrm{bc}$ & $133.57 \pm 6.09 \mathrm{ab}$ & $147.89 \pm 11.69 \mathrm{a}$ \\
Number of unfilled grain per panicle & $22.02 \pm 3.91 \mathrm{a}$ & $20.50 \pm 3.43 \mathrm{a}$ & $19.70 \pm 2.74 \mathrm{a}$ & $17.77 \pm 3.18 \mathrm{a}$ \\
Percent of filled grain per panicle & $81.48 \pm 2.28 \mathrm{a}$ & $84.05 \pm 1.85 \mathrm{a}$ & $85.93 \pm 2.04 \mathrm{a}$ & $87.76 \pm 1.88 \mathrm{a}$ \\
\hline
\end{tabular}

concentration of both T0.02 and T0.03 cause more positive effect than T0.01 and control group, showing no significant difference. The positive effects might be only based on the chelated $\mathrm{Ti}$ compounds which enhanced chlorophyll biosynthesis and enzymatic activities and increased photosynthesis and nutrient uptake, when applied to soils or onto leaves resulting in increased plant biomass or crop yield (Lyu et al., 2017).

\section{Number of filled grain, unfilled grain and percent of filled grain per panicle}

The number of filled grain was 105.32, 114.73, 133.57 and 147.89 grain per panicle (C, T0.01, T0.02 and T0.03), respectively, (Table 3 ), showing $8.93 \%, 26.82 \%$ and $40.42 \%$ (T0.01, T0.02 and T0.03), respectively, compared with the control group. Additionally, sn- $\mathrm{TiO}_{2}$ could offer more filling gain. This approach would decrease the number of unfilled gains, leading to increase in percentage of filled gain over the control group by $81.48 \%, 84.05 \%, 85.93 \%$ and $87.76 \%$ (T0.01, T0.02 and T0.03, respectively). Some studies revealed that how nanoparticle coating may cause positive results on physiology and biomass of plant. For example, application of $0.04 \% \mathrm{Ti}$ increased total yield of wandflower corms by $20 \%$ (Marcinek and Hetman, 2008). Many studies have observed and explained that $\mathrm{Ti}$ enhanced the growth of plant by participation in plant metabolism as a redox catalyst (TraettaMosca, 1913) and accumulated in as simulation organs (Geilmann, 1920). Moreover the optimal levels of Ti caused increased plant growth rate and reflected the intensity of chlorophyll content ( $\mathrm{N}^{2}$ emec and Káš, 1923).

\section{Ti content of digested plants}

The digested samples were analyzed using flame atomic absorption spectrometer for the determination of $\mathrm{Ti}$ at the wavelength of $298 \mathrm{~nm}$. The concentrations of $\mathrm{Ti}$ in the digested supernatant were recorded and calculated with the external calibration. From the result, the level of Ti was nondetectable indicating that the RD41 cultivar was not contaminated after treatments. It is nothworthy to know that the germination, soaking and spraying with a suspension of $\mathrm{sn}-\mathrm{TiO}_{2}$ were free from Ti contamination and, hence, safe for human and environment.

\section{Materials and Methods}

sn-TiO ${ }_{2}$ material

Anatase $\mathrm{sn}-\mathrm{TiO}_{2}$ nanoparticles with about $20 \mathrm{~nm}$ particle size were synthesized and characterized following our previous work (Theerakarunwong and Phanichphant, 2015). There concentrations of T0.01 $(0.01 \% \mathrm{w} / \mathrm{v})$, T0.02 $(0.02 \% \mathrm{w} / \mathrm{v})$ and
T0.03 $(0.03 \% \mathrm{w} / \mathrm{v})$ were suspended in water for $15 \mathrm{~min}$ in ultrasonic bath before germination.

Rice cultivar, germination and growth

Seeds of rice (Oryza sativa L.) cultivars RD41 immersed in 3 ranges of $\mathrm{TiO}_{2}$ concentration by $0.01 \% \mathrm{w} / \mathrm{v}, 0.02 \% \mathrm{w} / \mathrm{v}$ and $0.03 \% \mathrm{w} / \mathrm{v}$, compared with a control group. Then, the germinated seeds were placed in plastic trays overnight to enhance seed germination and further growth in 12 inch plastic pots with $10 \mathrm{~mL}$ suspension sn- $\mathrm{TiO}_{2}$ for 100 days. The control group was grown in the pots with no $\mathrm{sn}-\mathrm{TiO}_{2}$. Rice cultivar RD41 was soaked and sprayed with 3 different concentrations of $\mathrm{TiO}_{2}$ every 10 days for 3 replicates. Tiller number per plants, stem height and leaf chlorophyll were evaluated during the growing period of rice at tillering ( 40 days), flowering (70 days), and final harvesting (100 days), including the biomass, yield and final harvesting (100 days). Besides, final harvesting was subjected to AAS to confirm the Ti contaminated for all part of rice.

\section{Chlorophyll}

Approximately $0.1 \mathrm{~g}$ of tissue was ground with a pestle and mortar in $10 \mathrm{ml}$ of $80 \%$ acetone. The homogenate was centrifuged then the absorbance was measured at 663 and $647 \mathrm{~nm}$ in a spectrophotometer. Chlorophyll a and b were calculated using the equations provided by Lichtentalter (1987).

\section{Acid digestion}

$1.0 \mathrm{~g}$ of dried root, leaf and stem were acid digested with $5 \mathrm{~mL}$ concentrated $\mathrm{HNO}_{3}$ and $0.5 \mathrm{~mL} \mathrm{HClO}$ overnight. The extracts were then further digested for $20 \mathrm{~min}$ at $150^{\circ} \mathrm{C}$ until a transparent supernatant was formed, followed by heated at the temperature to $225^{\circ} \mathrm{C}$ for another $10 \mathrm{~min}$. After cooling, the supernatant was filtered through Whatman filter paper no. 42 and the specified distilled water was added to obtain 5 $\mathrm{mL}$ transparent supernatant until further analysis by AAS. Total Ti content was determined using AAS as described below.

\section{AAS analysis}

Dried rice tissues were analyzed for Ti content by AAS (PerkinElmer) equipped with nebulizer with air/acetylene flame. The concentration of $\mathrm{Ti}$ metal ions in the sample was investigated by its absorbance using AAS software with the external standard calibration curve. Ti element was determined by absorption/concentration mode compare to the digested blank solutions. Three replicate determinations of $\mathrm{Ti}$ were conducted on each sample.

\section{Statistical analysis}


The ANOVA analysis was carried out and significances of differences were tested at $p \leq 0.05$ between control and treatment. The group differences were analyzed by Duncan's New Multiple Range Test (DMRT).

\section{Conclusion}

The suspension of $\mathrm{sn}-\mathrm{TiO}_{2}$ increased biomass, chlorophyll content, growth, and yield of the rice cultivars RD41. The results of analysis showed that $\mathrm{sn}-\mathrm{TiO}_{2}$ can enhance plant metabolism and cell division. Chlorophyll content of $\mathrm{sn}-\mathrm{TiO}_{2}$ treated plants showed significant increase by the activation of photochemical reaction of rice. The concentration of 0.02 and $0.03 \% \mathrm{w} / \mathrm{v}$ was considered the highest affecting the plant growth and caused increases in the yield of rice. However, $0.02 \% \mathrm{w} / \mathrm{v}$ sn- $\mathrm{TiO}_{2}$ should be selected as the optimal concentration to enhance rice production, which is much safer than higher concentrations of $\mathrm{Ti}$. Hence, sn- $\mathrm{TiO}_{2}$ treatments by soaking and spraying can increase biomass and quality of rice cultivars RD41. Moreover, Ti element was not detected for all concentration treated in dried sample examined by AAS. This finding can be used as information on the potential influence of $\mathrm{TiO}_{2}$ material on yield and antioxidant defense mechanism of crops.

\section{Acknowledgments}

This work was financially supported by Nakhonsawan Rajabhat University, Thailand.

\section{References}

Carvajal M, Alcaraz CF (1998) Why titanium is a beneficial element for plants. J Plant Nutr. 21: 655-664.

Carvajal M, Martínez-Sanchez F, Pastor JJ, Alcaraz CF (1995) Leaf spray with $\mathrm{Ti}$ (IV) ascorbate improves the iron uptake and iron activity in Capsicum annuum L. plants. In Abadía J. (ed.) Iron Nutrition in Soils and Plants: 7th International Symposium on Iron Nutrition and Interactions in Plants, Zaragoza, Spain, June 27-July 2, 1993

Cigler P, Olejnickova J, Hruby M, Csefalvay L, Peterka J, Kuzel S (2010) Interactions between iron and titanium metabolism in spinach: a chlorophyll fluorescence study in hydropony. J Plant Physiol. 167(18):1592-1597.

Cox A, Venkatachalam P, Sahi S, Sharma N (2016) Silver and titanium dioxide nanoparticle toxicity in plants: A review of current research. Plant Physiol Bioch. 107: 147-163.

Cui J, Ma Z, Xu Z, Zhang H, Chang T, Liu H (2009) Effects of supplemental lighting with different light qualities on growth and physiological characteristics of cucumber, pepper and tomato seedlings. Acta Hortic. Sinica. 36:663-670.

Owolade OF, Ogunleti DO (2008) Effects of titanium dioxide on the diseases, development and yield of edible cowpea. J Plant Prot Res. 48: 329-335.

Hatami M, Ghorbanpour M (2014) Defense enzyme activities and biochemical variations of Pelargonium zonale in response to nanosilver application and dark storage. Turk J Biol. 38: 130-139.

Jaberzadeh A, Moaveni P, Moghadam T, Zahedi H (2013) Influence of Bulk and Nanoparticles Titanium Foliar Application on some Agronomic Traits, Seed Gluten and Starch Contents of Wheat Subjected to Water Deficit Stress. Not Bot Horti Agrobo. 41: 201-207.

Karami A, Sepehri A (2018) Nano titanium dioxide and nitric oxide alleviate salt induced changes in seedling growth, physiological and photosynthesis attributes of barley, ZEMDIRBYSTE. 105: 123-132.

Konishi K, Tsuge T (1936) Inorganic constituents of greenmanure crops. J Agric. Chem Soc. 12: 916-930.

Kovacik P, Hudec J, Ondrisik P, Poliakova N (2014) The effect of liquid Mg-Titanic on creation of winter wheat phytomass. Res J Agri Sci. 46: 125-131.

Lichtenthaler HK (1987) Chlorophylls and carotenoids - pigments of photosynthetic biomembranes. Methods Enzymol. 148: 350-382.

Linglan M, Chao L, Chunxiang Q, Sitao Y, Jie L, Fengqing G, Fashui $H$ (2008) Rubisco activase mRNA expression in spinach: Modulation by nanoanatase treatment. Biol Trace Elem Res. 122(2): 168-178.

Lyu S, Wei X, Chen J, Wang C, Wang X, Pan D (2017) Titanium as a Beneficial Element for Crop Production. Front Plant Sci. 8: 597-597.

Marcinek B, Hetman J (2008) The effect of foliage feeding on the structure of yield, dry weight content and macroelements in the corms of sparaxis tricolor Ker-Gawl. Acta Sci Pol Hortorum Cultus. 7(4): 89-99.

Mohammadi R, Maali-Amiri R, Mantri NL (2014) Effect of $\mathrm{TiO}_{2}$ nanoparticles on oxidative damage and antioxidant defense systems in chickpea seedlings during cold stress. Russ J Plant Physl. 61(6): 768-775.

Němec A, Káš V (1923) Studien uber die physiologische Bedeutung des titanium Pflanzenorganismus. Biochem Z. 140: 583-590.

Owolade OF, Ogunleti DO (2008) Effects of titanium dioxide on the diseases, development and yield of edible cowpea. EJEAF Che. 48: 329-335.

Geilmann W (1920) Uber die Verbreitung des Titans in Boden und Pflanzen. J Landwinsch. 68: 107-124.

Simon L, Hajdu F, Balogh A, Pais I (1998) Effect of titanium on growth and photosynthetic pigment composition of Chlorella pyrenoidosa (green alga). II. Effect of titanium ascorbate on pigment content and chlorophyll metabolism of chlorella, Pais New results in the research of hardly known trace element and their role in the food chain. University of Horticultural and Food Science, Budapest. pp. 87-101.

Servin A, Elmer W, Mukherjee A, De la Torre-Roche R, Hamdi H, White JC, Bindraban P, Dimkpa C (2015) A review of the use of engineered nanomaterials to suppress plant disease and enhance crop yield. J Nanopart Res. 17(2):1-21.

Theerakarunwong C, Chouychai W (2013) Efficiency of titanium dioxide on mungbean seed sterile and their nanotoxicity to mungbean growth in vitro. Intl J Agric Biol. 15(5): 1039-1042.

Theerakarunwong DC, Phanichphant S (2015) Photocatalytic degradation of aromatic pollutants in aqueous solution over $\mathrm{TiO}_{2}$ catalyst. Chiang Mai J Sci. 42(4): $939-945$.

Traetta-Mosca F (1913) Titanium and the rare metals in the ash of the leaves of Kentucky tobacco cultivated in Italy. Gazz Chim Ital. 43: 437-440.

Tripathi DK, Shweta, Singh S, Singh S, Pandey R, Singh VP, Sharmae NC, Prasadf SM, Dubeya NK, Chauhan DK (2017) An overview on manufactured nanoparticles in plants: Uptake, translocation, accumulation and phytotoxicity. Plant Physiol Biochem. 110: 2-12.

Wang WN, Tarafdar JC, Biswas P (2013) Nanoparticle synthesis and delivery by an aerosol route for watermelon plant foliar uptake. J Nanopart Res. 15(1417): 1-13.

Zahra Z, Waseem N, Zahra R, Lee H, Badshah MA, Mehmood A, Choi HK, Arshad M (2017) Growth and metabolic responses of rice (Oryza sativa L.) cultivated in phosphorus-deficient soil amended with $\mathrm{TiO}_{2}$ nanoparticles. J Agric Food Chem. 65(28): 5598-5606. 